\title{
Use of Tape Measure in People with or without Back Pain in Assessment of Reposition Error
}

\author{
Bel Ağrısı Olan ve Olmayan Kişilerde Repozisyon Hatasının \\ Değerlendirilmesinde Şerit Mezura Kullanımı
}

\author{
Bilge KARA, Arzu GENC, Yucel YILDIRIM, Nursen ILCIN \\ Dokuz Eylul University, School of Physical Therapy, Inciraltu, Izmir, Turkey
}

Correspondence address: Bilge KARA / E-mail: bparlak@deu.edu.tr

\begin{abstract}
AIM: Examining lumbar repositioning error (RE) using a tape measure in nonspecific low back pain (NLBP) and control groups and determining whether RE is different in subjects with nonspecific back pain than in controlled subjects.

MATERIAL and METHODS: The study was totally applied to 36 subjects of whom 18 were healthy subjects and 18 were NLBP patients. The ability of the subjects to take the targeted positions was assessed. In subjects with NLBP the evaluation of the pain was assessed by using Visual Analog Scale (VAS), and disability measurement was made using Oswestry Disability Index (ODI).

RESULTS: RE was found in all the measurements except for lumbar flexion with eyes open $(p=0.15)$ in control group ( $p<0.05)$. There were RE for all the measurements in NLBP grpup $(p<0.05)$. When RE of two groups compared only lumbar flexion with eyes open measurement $(p=0.04)$ in NLBP group was higher then control group.

CONCLUSION: As a result of our study, it has been seen that RE measurement of the lumbar spine with tape measure, which is cheap and clinically practical, is a reliable method, and can be used in the assessment of NLBP patients and in the determination of the rehabilitation program.
\end{abstract}

KEYWORDS: Low back pain, Reposition error, Posture, Range of motion

öz

AMAÇ: Şerit mezura kullanarak nonspecific low back pain (NLBP)' li hastalarda sağlıklı kişilere göre repozisyon hatalarının olup olmadığını incelemektir.

YÖNTEM ve GEREÇ: Çalışmaya 18'i sağlıklı, 18'i NLBP’li olmak üzere 36 kişi alındı. Kişilerin hedef pozisyonu alabilmeleri değerlendirildi. NLBP hastalarda ağrı görsel analog skalasıyla ve özürlülük ölçümleri Oswestry Disability Index (ODI) ile yapıldı.

BULGULAR: NLBP'li grupta tüm değerlendirme parametrelerinde repozisyon hatası bulunurken $(p<0.05)$, kontrol grubunda gözler açık lumbar flexion değerlendirmesi $(p=0.15)$ dışındaki tüm ölçümlerde repozisyon hatası vardı $(p<0.05)$. İki grubun repozisyon hatası ölçümleri karşılılaştırıldığında sadece gözler açık olarak yapılan lumbar flexion ölçümünde fark saptandı $(p=0.04)$. Repozisyon ağrı ve özürlülük düzeyleri arasında anlamlı koresyon bulunmadı ( $p>0.05$ ).

SONUÇ: Lomber spinanın repozisyon ölçümünde şerit mezura kullanımı ucuz olup, klinik olarak pratik ve güvenilir bir metotdur. NLBP 'li hastaların değerlendirmesinde kullanılacak güvenilir bir metoddur.

ANAHTAR SÖZCÜKLER: Bel ağrısı, Repozisyon hatası, Postür, Eklem hareket açıklığı

\section{INTRODUCTION}

Proprioception can be defined as the sensation of position and movement at joints; the sense of force, effort and heaviness associated with muscular contraction; or the sensation of perceived timing of muscular contraction. The ability to perceive the movement or orientation of a body segment in space is known as position sense $(7,13,14,26,29,37)$.

Proprioception, which plays a very important role in human movement, can determine the body position in space with afferent inputs from various receptors, and enables the body to control the movements properly Proprioception describes those sensations generated within the body which contribute to an awareness of the relative orientation of body parts, both at rest and in motion $(3,5,16,18,24)$. A complex term, proprioception, includes such motions as joint and position sense, speed, muscular control and contraction timing. The proprioceptive system is dependent upon simultaneous activity in a number of types of mechanoreceptor afferent neurons. Mechanoreceptors provide information for reflex 
regulation of muscle tone, for awareness of position sense and movement sense and have been isolated in most spinal tissues (15). Intact proprioception is essential for movement control. In the spine, proprioceptive information is provided by structures present in the spinal ligaments, facet joints, intervertebral discs, and paraspinal muscles. Muscle spindle density is high in deep paraspinal rotators, which are small muscles spanning one or two segments of the spine. It is believed that the spindles in these muscles act as kinesthetic sensors that monitor trunk position and movement. It is these muscle receptors that are more likely responsible for information in the midrange of trunk motions (21). While joint receptors cannot be discounted, these structures are thought to provide more input toward the end range of joint positions. However, altered joint afferent information can alter muscle activation. Consequently proprioceptive information from both muscle and joint receptors may be an important aspect of trunk control of motion $(3,16,23)$. Proprioception is considered essential for the control of human movement and can be important in diagnosing motor control impairment $(21,25)$. Patients with low back pain (LBP) present with both altered motor control and impaired spinal reposition sense. Impaired motor control findings with low back pain include balance impairment, longer reaction times and decreased psychomotor speed, changes in trunk feed-forward control (transversus abdominus) and (loss of muscular stabilization cross sectional area loss of the multifidus) (3). The studies have shown that proprioceptive sense is affected not only in peripheral joints and cervical spine injury but in lumbar injury and in LBP, as well. It has been shown in peripheral joints that stress or injury to a joint caused by instability may result from an individual's inability to control joint position accurately. Proprioceptive deficit may lead to delayed neuromuscular protective reflexes and coordination such that muscle contraction occurs too late to protect the joint from excessive joint movement. It has been hypothesized that this may lead to abnormal loading transmitted repetitively across joint surfaces, resulting in pain and articular damage. Studies have demonstrated reduced elements of proprioception in injured peripheral joints and the cervical spine $(5,8,9,10,15,16,17)$. However, knowledge of this important mechanism in relation to lumbar injury and low back pain (LBP) is yet limited. Newcomer et al. reported significantly larger repositioning error in patients with LBP in trunk flexion and significantly lower error in trunk extension when compared to a control group (21). Field et al. found less variability in repositioning error in their LBP group and Parkhurst et al. found no correlation between directly measured proprioceptive variables and $\mathrm{LBI}$, but instead reported its association with the asymmetry indices derived from these variables $(8,24)$. Finally, several studies demonstrated no proprioceptive impairments in individuals reporting LBP or injury. Differences in test conditions (body position, planes of motion, whether or not vestibular system is involved, lower body constraint), and subject characteristics could explain some of the divergent results in the literature. Despite the above uncertainties, widely reported deficits in postural control and altered patterns of muscle response to sudden trunk loading among patients with LBP are hypothesized to be, at least in part, the result of injury to mechanoreceptors embedded in the soft tissues surrounding the lumbar spine. However, an alternative hypothesis would be that impaired spinal proprioception is a pre-existing risk factor that predisposes individuals to $\mathrm{LBI}$ $(22,23,29)$.

That is the reason why reposition errors (RE) measurement is frequently used in proprioception assessment. Clinicians may not always be able to make practical RE assessments in the LBP rehabilitation through the former technologies that entail rather costly and complicated methods $(18,28,36)$.

The aim of this study was to examine lumbar repositioning error (RE) using a tape measure in nonspecific low back pain (NLBP) and control groups and, determine whether RE was different in subjects with nonspecific back pain from in control subjects.

\section{MATERIAL and METHODS}

\section{Subjects}

The study was totally applied to 36 subjects of whom 18 were healthy subjects and 18 were NLBP patients. Trunk repositioning error was measured with a tape measure

\section{Inclusion Criteria}

- To have had NLBP for at least two years

- Not to have any other neurological or orthopedic pathology apart from NLBP.

- To volunteer for the study

Subjects were excluded if low back pain was so severe as to prevent co-operation with the study, and control subjects could not have had complaints of discomfort over the low back region for more than three months in duration and had to have been free of low back pain for at least the previous year.

Patients were informed as required and their consents were obtained for assessments. During our study, required explanation was given to our patients and required approval was obtained from them for the evaluations and participation into the study.

\section{Instrumentation and Procedure}

Our measurement instrument for this study was a simple, flexible one-meter plastic tape. The subjects were asked to stand upright in front of the mirror with the feet apart from each other about the shoulders' width, and with the arms near the body. This posture was taken as the subjects' usual posture. After that, the subjects were taught the rules of upright position and asked to position themselves in front of the mirror. This posture was recorded as the upright position of the subject and the measurements for the posture analysis were recorded by means of a tape measure. 
Lumbar flexion (Schober Test): The patient stands with the feet apart from each other about the shoulders' width, The patient flexes the trunk forward. A tape measure is used to measure the distance between the spinous processes of $C 7$ and S2. A measure is taken in the start position, and at the limit of motion. The difference between the two measures is the thoracolumbar spinal ROM (28).

Lumbar lateral flexion: The patient is standing with the feet shoulder wide apart and flexes laterally. A tape measure is used to measure the distance between the tip of the third digit and the floor (23).

Reposition error. Subjects were requested to actively move as slowly as possible to the target position determined by the examiner according to the sensor recording during the trial. When the subject reached the target position, they were told to hold the position for $5 \mathrm{~s}$ and return to neutral position and then replicate the target position. In order to asses the $\mathrm{RE}$, the subjects' lumbar spine was brought to $5 \mathrm{~cm}$ flexion from the initial position and they were required to perceive and learn that position for 30 seconds. Then, the position was repeated actively in front of the mirror to obtain visual feedback, after which the same position was asked them to do with eyes closed. The target position was accepted as " $0 \mathrm{~cm}$ " and any deviation (-) from such target position was recorded as (-) undershooting, and (+) overshooting. The same procedure was actively repeated in the $10 \mathrm{~cm}$ right and left lateral flexion positions respectively $(4,9,12,25)$.

Pain. Measures of pain and pain effect were obtained using visual analog scale. The subjects were asked to mark the intensity of the pain which they felt during the activity on a line divided into ten $(20,30)$.

Disability measurement. The Oswestry disability index was used in the evaluation of the subjects' disability levels. ODI is a ten-item scale instrument with six response-alternatives for each item. The total score ranges from 0 to 100: 0 to 20 (minimal disability), 20 to 40 (moderate disability), 40 to 60 (severe disability) and 60 to 100 (extremely severe to crippling disability). The ODI rates pain intensity and the functional ability degree of an individual such as personal care, lifting, walking, sitting, standing, sleeping, sex life and traveling all of which are affected by back pain (27).
Data Analysis: Descriptive statistics include frequency distribution of categorical variables as well as mean and standard deviations for continuous variables. Mann Whitney $\mathrm{U}$ Test was performed to compare control and NLBP groups by means of their descriptive characteristics (age and BMI). The Wilcoxon nonparametric test was used for the statistical comparison between test conditions (Intragroup analyses) and Mann Whitney $U$ test was performed to compare RE of two groups (Intergroup analyses). In the NLBP group, the association between $\mathrm{RE}$, pain and disability level were examined by computation of Spearman's rank correlation coefficients. The statistics were analyzed with the Statistical Package for Social Sciences (SPSS for Windows Release 11.0; SPSS Inc. Chicago, IL, USA). Values of $\mathrm{p}<0.05$ were considered statistically significant.

\section{RESULTS}

The demographic characteristics of NLBP and control group subjects can be seen in Table I. The table shows that there was not statistically difference in age and Body Mass Index (BMI) between two groups and groups were homogeneous in the beginning of the study.

\section{Intragroup Analyses of RE:}

RE was found in all the measurements except for lumbar flexion with eyes open $(p=0.15)$ in control group $(p<0.05)$. RE was present for all the measurements in NLBP group $(p<0.05)$.

\section{Intergroup Analyses of RE:}

The average and standard deviation values of $R E$ measurements for the target positions are given in Table II. When RE of two groups compared only lumbar flexion with eyes open measurement $(p=0.04)$ in NLBP group was higher then control group (Table II).

\section{Pain and Disability Measurements:}

During the assessment of the NLBP cases, it was determined that the mean pain severity was $6.13 \pm 2.5$, and there wasn't a correlation between the pain severity and RE.

Mean Oswestry scores of NLBP subjects were found to be $37.2 \pm 13.1$, and no statistically significant correlation was identified between the disability level and RE.

Table I: Characteristics of Subjects

\begin{tabular}{|c|c|c|c|}
\hline & NLBP & Control & $\mathbf{p}$ \\
\hline Age (years) mean $\pm S D$ & $48.2 \pm 9.7$ & $44.5 \pm 3.9$ & 0,11 \\
\hline BMI $\left(\mathrm{kg} / \mathrm{m}^{2}\right)$ mean $\pm S D$ & $28.6 \pm 3.9$ & $26.9 \pm 2.5$ & 0,19 \\
\hline $\begin{array}{l}\text { Sex } \\
\text { Female } \\
\text { Male }\end{array}$ & $\begin{array}{c}10(55.6 \%) \\
8(44.4 \%)\end{array}$ & $\begin{array}{l}9(50.0 \%) \\
9(50.0 \%)\end{array}$ & \\
\hline VAS $(0-10 \mathrm{~cm})$ & $6.1 \pm 2.5$ & - & \\
\hline Oswestry Score (0-100) & $37.2 \pm 13.1$ & - & \\
\hline
\end{tabular}

NLBP: Nonspesific low back pain, BMI: Body mass Index, VAS: Visual Analog Scale, ${ }^{*}: p<0.05$ 
Table II: Differences in the Mean, Standard Deviation (SD) of RE in cm in the Trials of the Testers A,B,C

\begin{tabular}{|c|c|c|c|c|}
\hline & & $\begin{array}{l}\text { Control Group } \\
\text { Mean } \pm \text { SD }\end{array}$ & $\begin{array}{l}\text { NLBP Group } \\
\text { Mean } \pm \text { SD }\end{array}$ & $\mathbf{p}$ \\
\hline \multirow{2}{*}{ Flex } & EO & $0.05 \pm 0.16$ & $0.70 \pm 1.42$ & $0.04^{*}$ \\
\hline & $\mathrm{EC}$ & $0.19 \pm 0.54$ & $0.20 \pm 1.54$ & 0.56 \\
\hline \multirow{2}{*}{ Lat Flex L } & EO & $0.13 \pm 0.83$ & $0.16 \pm 1.19$ & 0.88 \\
\hline & EC & $0.91 \pm 1.40$ & $0.10 \pm 1.61$ & 0.13 \\
\hline \multirow{2}{*}{ Lat Flex $\mathbf{R}$} & $\mathrm{EO}$ & $0.66 \pm 1.09$ & $0.33 \pm 1.34$ & 0.50 \\
\hline & $\mathrm{EC}$ & $-0.94 \pm 1.47$ & $0.03 \pm 1.40$ & 0.10 \\
\hline
\end{tabular}

NLBP: Nonspesific low back pain; EO: Eyes open; EC: Eyes closed; Flex: Flexion; Lat Flex L: Lateral flexion left; Lat Flex R: Lateral flexion right; *: $p<0.05$

\section{DISCUSSION}

Proprioception is considered essential for the control of human movement and can be important in diagnosing motor control impairment. Moreover, proprioception was defined in the dictionary as the awareness of posture, movement and changes in equilibrium and the knowledge of position, weight and resistance of objects in relation to the body $(2,11,16,18,32,34,35)$.

Patients with low back pain were $33 \%$ more susceptible to trunk repositioning errors then healthy controls. Older adults may also suffer from a deterioration of their trunk proprioception. (21). Numerous studies have examined repositioning error of the low back in subjects without LBP $(21,22)$.

The joint stability that is impaired by injury and stress can lead to losses in the movement control of the joints and damage proprioception. Furthermore, proprioceptive deficits cause the neuromuscular protective muscle reflexes and coordination to slow down. Protective muscle contractions in excessive joint movements form too late, thus exposing the joint surface to overloading. The resultant pain and articular damage weakens proprioception. This mechanism similarly applies to the spine $(15,16,25)$.

In the low back pain problems, which are often seen in the general population, the measurement of proprioception holds a light to the area of assessment and rehabilitation program $(7,25)$.

Although studies regarding the measurement of position mostly focus on peripheral joints in extremities, there are relatively fewer studies related to the position sense of the spine, made up of multiple joints. Studies investigating proprioception have used position sense or repositioning error as a measure of proprioceptive ability $(2,3,12,26)$.

Since proprioception is a complex notion, its measurement is difficult. RE measurement is often used in spinal proprioception evaluation and many studies have proved that the rate of RE is higher in NLBP patients than in healthy subjects $(1,6,8,15,19,31,33)$. In place of these expensive technological methods, we preferred to use the tape measure and showed that it is an applicable method in the evaluation of proprioception and has no less intra-inter tester reliability.

In our study, in order to evaluate RE we used the tape measure, which has long been used in NEH and posture assessment and found the reliability to be very high in lumbar RE measurement, as we hypothesized.

RE was found in all the measurements in both groups except for lumbar flexion with eyes open in control group. We believe that reason of there was no RE in lumbar flexion with eyes open in control group might frequency usage of flexion activity in daily life. On the contrary RE was found in laterally flexion activity in two groups. We think that laterally flexion is not the pre-learned function and it has not frequency usage in daily life and it can be the reason of this.

Proprioceptive damage results in dysfunction in stabilization muscles of lumbar spine and therefore positioning according to neutral zone becomes difficult $(1,12,18,21,25)$. In our study, upright posture, both in NLBP patients and healthy subjects was found to be impaired in comparison with neutral position.

Newcomer and et al, who evaluated RE in 20 LBP patients and 20 healthy subjects found no correlation between RE and pain severity. They interpreted this as an inverse proportion between the pain intensity and RE inasmuch as the patients benefited from the pain as an afferent stimulant (22). Likewise, no correlation was found between the RE and pain severity / disability levels, which are considered to be major complications of NLBP.

As a consequence, further investigations in different studies for RE measurement on more NLBP cases are needed.

In conclusion, we recommended in our study the use of the measure tape that is already used clinically for the measurement of lumbar repositioning error, as it has been proven to be easier to apply and inexpensive. 


\section{REFERENCES}

1. Leinonen $V$, Kankaanpää $M$, Luukkonen $M$, Kansanen $M$, Hänninen $O$, Airaksinen O, Taimela S: Lumbar paraspinal muscle function, perception of lumbar position, and postural control in disc herniation-related back pain. Spine 28(8):842848, 2003

2. Åsell $M$, Sjölander $P$, Kerschbaumer $H$, Djupsjöbacka $M$ : Are lumbar repositioning errors larger among patients with chronic low back pain compared with asymptomatic subjects? Arch Phys Med Rehabil 87:1170-1176, 2006

3. Brumagne S, Lysens R, Swinnen S, Verschuereren S: Effect of paraspinal muscle vibration on position sense of the lumbosacral spine. Spine 24(13): 1328-1331, 1999

4. Brumagne S, Lysens R, Spaepen A: Lumbosacral repositioning accuracy in standing posture: A combined electrogoniometric and videographic evaluation. Clin Biomech 14(5):361-363, 1999

5. Brumagne S, Cordo P, Lysens R, Verschueren S, Swinnen S: The role of paraspinal muscle spindles in lumbosacral position sense in individuals with and without low back pain. Spine 25:989-994, 2000

6. Nies N, Sinnott PL: Variations in balance and body sway in middle- aged adults. Subjects with healthy backs compared with subjects with low-back dysfunction. Spine 16: 325-330,1991

7. Descarreaux M, Blouin JS, Teasdale N: Repositioning accuracy and movement parameters in low back pain subjects and healthy control subjects. Eur Spine J 14:185-191, 2005

8. Field E, Abdel-Moty E, Khalil T, Asfour S: Postural proprioception in healthy and back-injured adults. Phys Ther 71: S104-S105, 1991

9. Gill KP, Callaghan MJ: The measurement of lumbar proprioception in individuals with and without low back pain. Spine 23:371-377, 1998

10. Greene HS, Cholewicki J, Galloway MT, Nguyen CV, Radebold A: A history of low back injury is a risk factor for recurrent back injuries in varsity athletes. Am J Sports Med 29:795-800, 2001

11. Holm S, Indahl A, Solomonow M: Sensorimotor control of the spine. J Electromyogr Kinesiol 12:219-234, 2002

12. Koumantakis GA, Winstanley J, Oldham JA: Thoracolumbar proprioception in individuals with and without low back pain: Intratester reliability, clinical applicability, and validity. J Orthop Sports Phys Ther 32:327-335, 2002

13. Lam SS, Jull G, Treleaven J: Lumbar spine kinesthesia in patients with low back pain. J Orthop Sports Phys Ther 29:294-299, 1989

14. Laskowski ER, Newcomer-Aney K, Smith J: Proprioception. Phys Med Rehabil Clin N Am 11: 323- 340, 2000

15. Lehman GJ: Biomechanical assessments of lumbar spinal function. How low back pain sufferers differ from normals. Implications for outcome measures research. Part l: Kinematic assessments of lumbar function. J Manipulative and Physiol Ther 27(1): 57-62, 2004
16. Leinonen V, Määttä $S$, Taimela $S$, Herno A, Kankaanpää $M$, Partanen J, Kansanen M, Hänninen O, Airaksinen O: Impaired lumbar movement perception in association with postural stability and motor-and somatosensory-evoked potentials in lumbar spinal stenosis. Spine 27:975-983, 2002

17. Leinonen $V$, Kankaanpää $M$, Luukkonen $M$, Kansanen $M$, Hänninen $\mathrm{O}$, Airaksinen $\mathrm{O}$, Taimela S: Lumbar paraspinal muscle function, perception of lumbar position, and postural control in disc herniation-related back pain. Spine 28(8): 842-848, 2003

18. Lephart SM, Pincivero DM, Giraldo JL, Fu FH: The role of proprioception in the management and rehabilitation of athletic injuries. Am J Sports Med 25(1):130-137, 1997

19. Marras WS, Lavender SA, Leurgans SE, Fathallah FA, Ferguson SA, Allread WG, Rajulu SL: Biomechanical risk factors for occupationally related low back disorders. Ergonomics 38: 337- 410, 1995

20. Mientjes MI, Frank JS: Balance in chronic low back pain patients compared to healthy people under various conditions in upright standing. Clin Biomech 14:710-716, 1999

21. Newcomer K, Laskowski ER, Yu B, Larson DR, An KN: Repositioning error in low back pain. Comparing trunk repositioning error in subjects with chronic low back pain and control subjects. Spine 25(2): 245-250, 2000

22. Newcomer KL, Jacobson TD, Gabriel DA, Larson DR, Brey $\mathrm{RH}, \mathrm{An} \mathrm{KN}$ : Muscle activation patterns in subjects with and without low back pain. Arch Phys Med Rehabil 83(6): 816-821, 2002

23. O'Sullivan PB, Burnett A, Floyd AN, Gadsdon K, Logiudice J, Miller D, Quirke H: Lumbar repositioning deficit in a specific low back pain population. Spine 28(10):1074-1079, 2003

24. Parkhurst TM, Burnett CN: Injury and proprioception in the lower back. J Orthop Sports Phys Ther 19:282-295, 1994

25. Petersen CM, Zimmermann CL, Cope S, Bulow ME, EwersPanveno E: A new measurement method for spine reposition sense. J Neuroeng Rehabil 26:5-9, 2008

26. Radebold A, Cholewicki J, Polzhofer GK, Greene HS: Impaired postural control of the lumbar spine is associated with delayed muscle response times in patients with chronic idiopathic low back pain. Spine 26:724-730, 2001

27. Roland M, Fairbankt J: The Roland-Morris Disability Questionnaire and the Oswestry Disability Questionnaire. Spine 25(24): 3115-3124, 2000

28. Schober E, Waldhoer T, Rami B, Hofer S: Incidence and time trend of type 1 and type 2 diabetes in Austrian children 19992007. Austrian Diabetes Incidence Study Group. J Pediatr 155(2):190-193, 2009

29. Solomonow M: Sensory - motor control of ligaments and associated neuromuscular disorders. J Electromyogr Kinesiol 16:549-567, 2006

30. Stephenson NL, Herman JA: Pain measurement: A comparison using horizontal and vertical visual analogue scales. Appl Nurs Res13(3):157-158, 2000 
31. Stevens VK, Bouche KG, Mahieu NN, Cambier DC, Vanderstraeten GG, Danneels LA: Reliability of a functional clinical test battery evaluating postural control, proprioception and trunk muscle activity. Am J Phys Med Rehabil 85(9):727-736, 2006

32. Swinkels A, Dolan P: Regional assessment of joint position sense in the spine. Spine 23(5): 590-597, 1998

33. Taimela $S$, Kankaanpää $M$, Luoto $S$ : The effect of lumbar fatigue on the ability to sense a change in lumbar position. A controlled study. Spine 24:1322-1327, 1999
34. Tousignant M, Poulin L, Marchand S, Viau A, Place C: The Modified-Modified Schober Test for range of motion assessment of lumbar flexion in patients with low back pain: A study of criterion validity, intra- and inter-rater reliability and minimum metrically detectable change. Disabil Rehabil 20, 27(10):553-559, 2005

35. Troke M, Schuit D, Petersen CM: Reliability of lumbar spinal palpation, range of motion, and determination of position. BMC Musculoskelet Disord 8:103, 2007

36. Wilson SE, Granata KP: Reposition sense of lumbar curvature with flexed and asymmetric lifting postures. Spine 28: 513-518, 2003 